<総 説 $>$

(受理 : 平成 29 年 3 月 13 日)

\title{
アミロースーポリ乳酸包接超分子ポリマーの化学一酵素合成 Chemo-Enzymatic Synthesis of Amylose-Polylactide Inclusion Supramolecular Polymers
}

\author{
田中 知成 $*$ 門川 淳一** \\ Tomonari TANAKA, Jun-ichi KADOKAWA
}

\section{1.はじめに}

酵素を触媒とするグリコシル化反応は，温和な条件下で 位置抒よび立体選択的にグリコシド結合を構築できる非常 に有用な合成法である。グリコシド結合の形成に用いられ る酵素は主に, 糖転移酵素（トランスフェラーゼ）, 加水 分解酵素 (グリコシダーゼ), 加リン酸分解酵素 (ホスホ リラーゼ）に大別される ${ }^{1 \sim 6)} 。$ ホスホリラーゼは，無機リ ン酸存在下，糖鎖の非還元末端側のグリコシド結合を加 リン酸分解し，単糖の 1 - リン酸エステルと重合度のひ とつ小さい糖鎖を生成する反応を触媒する酵素である7 種々のホスホリラーゼの中で $\alpha$ ーグルカンホスホリラーゼ (E.C. 2.4.1.1，グリコーゲンホスホリラーゼあるいはス夕ー チホスホリラーゼとも呼ばれる。以降, 単にホスホリラー ゼと記す。）は, 動植物や微生物中に広く存在し, 最む研 究されているもののひとつである。本酵素は, 無機リン酸 存在下, グリコーゲンやデンプンなどの $\alpha-1,4-$ グルカン を非還元末端側から加リン酸分解し， $\alpha-\mathrm{D}-$ グルコース 1 -リン酸（G-1-P） を生成する反応を触媒する（スキー ム 1a）。生成するリン酸エステルの結合エネルギーがグリ コシド結合のエネルギーと同等であるため，この反応は可 逆的であり, 逆反応のグリコシル化反応むホスホリラーゼ

\footnotetext{
* 京都工芸繊維大学大学院工芸科学研究科

京都市左京区松ヶ崎橋上町 1 番地 ₹ 606-8585

Department of Biobased Materials Science, Graduate School of Science and Technology, Kyoto Institute of Technology Matsugasakihashikamicho, Sakyo-ku, Kyoto 606-8585, Japan

** 鹿児島大学大学院理工学研究科 鹿児島市郡元 1-21-40 干 890-0065

Department of Chemistry, Biotechnology and Chemical Engineering, Graduate School of Science and Engineering, Kagoshima University

1-21-40, Korimoto, Kagoshima 860-0065, Japan
}

によって触媒される（スキーム $1 \mathrm{~b} ）$ 。すおお, $\mathrm{G}-1-\mathrm{P}$ がグリコシル供与体となり，グリコシル受容体の非還元末 端に位置および立体選択的にグルコースが転移する。本グ リコシル化反応の位置および立体特異性は極めて厳密であ るため，ホスホリラーゼを触媒としたグリコシル化反応は 構造明確なオリゴ糖および多糖合成において非常に重要な 合成法である。グリコシル受容体に対して過剩の $\mathrm{G}-1-\mathrm{P}$ 存在下においては, グリコシル受容体の非還元末端へのグ ルコースの転移反応が連続的に進行することでホスホリラー ゼによる酵素触媒重合反応となり，グルコースが $\alpha-1,4$ 結合でつながった多糖であるアミロースが生成する ${ }^{8 \sim 10)}$ 。

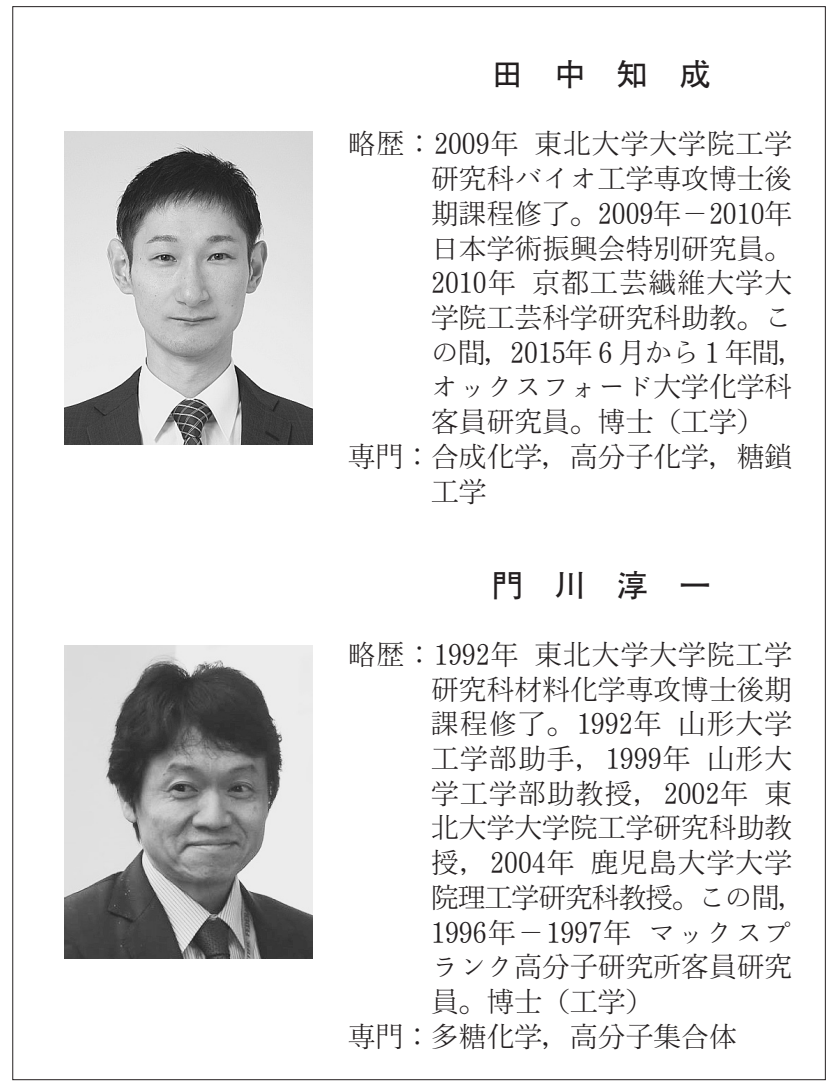




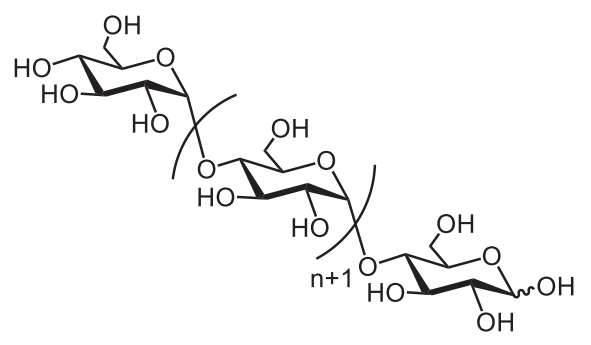

$+$

無機リン酸

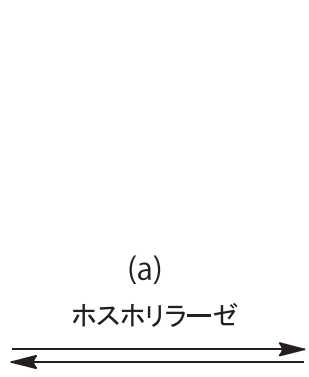

(b)

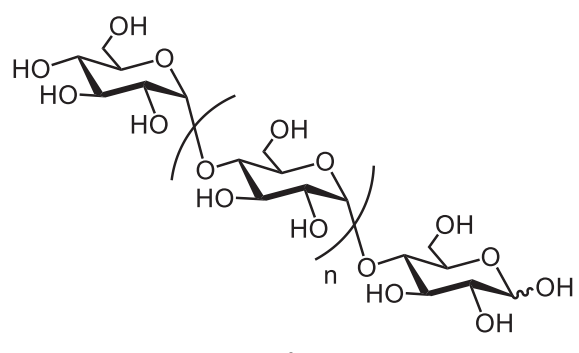

$+$

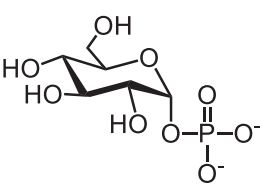

G-1-P

スキーム 1 ホスホリラーゼによる（a）加リン酸分解と（b）グリコシル化

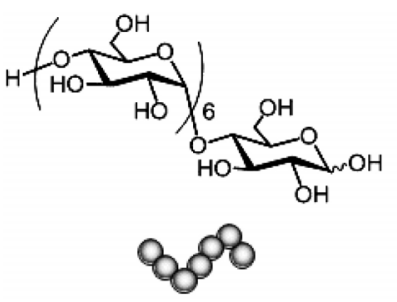

$\mathrm{G}_{7}$ (゙ライマー)

$+$

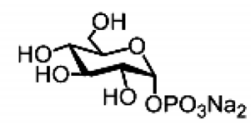

O-P

G-1-P (モノマー)

ホスホリラーゼ(触媒)

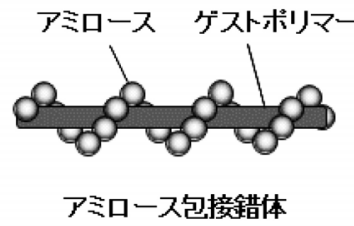

ゲストポリマー

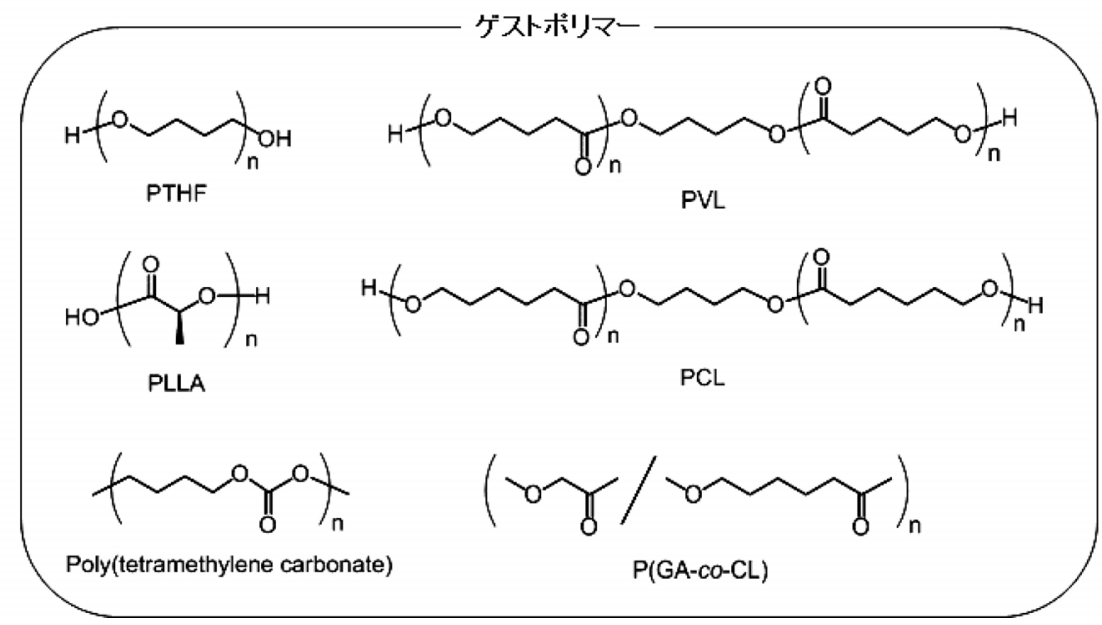

図 1 つる巻き重合によるアミロース包接錯体の合成

これにより得られるアミロースの分子量分布は狭く, 分子 量は $\mathrm{G}-1-\mathrm{P}$ とグリコシル受容体の仕込比によってある程 度制御できる ${ }^{11)}$ 。アミロースは, 自然界でエネルギー貯蔵 物質として働くデンプンの一成分であるが，あう一つの成 分であるアミロペクチンとの完全な分離は困難であること から，この酵素触媒重合は純粋なアミロースを得る有力な 手法である。

アミロースはらせん状多糖であり, らせん内部の疎水性 空間に比較的低分子量の疎水性化合物を包接することが知
られている。しかし，アミロースによる高分子化合物の包 接は，疎水性相互作用のみがドライビングフォースである ため非常に困難であり，その報告例は多くない12 22)。著 者らは，ホスホリラーゼを触媒とするアミロースの酵素合 成反応に揖いて，疎水性高分子（ゲストポリマー）を共存 させると，グリコシル受容体であるマルトオリゴ糖の非還 元末端から伸長するアミロース鎖がゲストポリマーに巻き つき，アミロースのらせん内部にゲストポリマーが取り込 まれた包接錯体が生成することを報告した（図 1)。この 
ホスホリラーゼを触媒, $\mathrm{G}-1-\mathrm{P}$ をモノー, マルトヘプ タオース $\left(\mathrm{G}_{7}\right)$ をプライマーとする酵素触媒重合反応は, 植物のつるが棒に巻きつくさまに似ていることから，“つ る巻き重合” と名付けた ${ }^{23,24)}$ 。本反応において, ポリテト ラヒドロフラン (PTHF) などのポリエーテル, ポリ（ $\delta-$

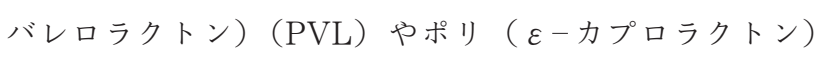
(PCL)，ポリグリコール酸と PCL の共重合体 ( $\mathrm{P}\left(\mathrm{GA}-c o^{-}\right.$ CL)）などのポリエステル, ポリテトラメチレンカーボネー トなど，さまざまなゲストポリマーをアミロースらせん内 部に包接することができることを報告し，アミロースによ る高分子の包接を架橋点として利用したマテリアル開発へ

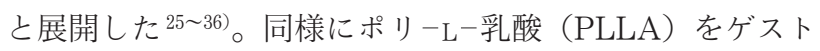
ポリマーとした場合にはアミロース-PLLA 包接錯体が生 成するが，ポリーD一乳酸（PDLA）およびポリーDL-乳酸 (PDLLA) の場合には包接錯体は生成しなかった ${ }^{37)} 。 こ$ れは, アミロースのらせん内部の疎水性空間がゲストポリ マーであるポリ乳酸のキラリティを認識したことを意味し ている。

これらの知見を基に，著者らは近年，つる巻き重合にお けるゲストポリマーの末端にプライマーの $\mathrm{G}_{7}$ を結合した プライマーーゲストポリマー複合体を化学合成し, これを 用いてつる巻き重合を行うと, アミロースとゲストポリマー から構成される新奇な高分子の集合体（超分子ポリマー） が合成できることを見いだした。本総説では，PLLAの 末端に $\mathrm{G}_{7}$ を有するプライマーーゲストポリマー複合体の 化学合成上, これらを用いたつる巻き重合によるアミロー ス-PLLA 包接超分子ポリマーの合成, および得られた超 分子ポリマーのマテリアル化について概説する。

\section{2. 新奇アミロースーポリ乳酸包接超分子ポリマー の合成}

つる巻き重合によるアミロース包接錯体の合成に基づい
て，ゲストポリマーの末端にプライマーの $\mathrm{G}_{7}$ を結合した プライマーーゲストポリマー複合体を用いてつる巻き重合 を行えば, $\mathrm{G}_{7}$ から伸長するアミロース鎖が他のプライマーー ゲストポリマー複合体分子のポリマー鎖部分を包接し，さ らに包接されたゲストポリマー末端の $\mathrm{G}_{7}$ からあアミロー ス鎖が伸長して別の分子のポリマー鎖部分を包接すること が繰り返されることで，アミロースと合成高分子からなる 新奇な包接超分子ポリマーを合成することができると考え た。そこで，無保護の $\mathrm{G}_{7}$ を原料として 2 -クロロ $-1,3-シ ゙$ メチルイミダゾリニウムクロリド (DMC) を用いるアノ マー位の直接アジド化反応によって $\beta$-マルトヘプタオシ ルアジド $\left(\mathrm{G}_{7}-\mathrm{N}_{3}\right)$ を合成した後, 末端にアルキンを有す る PLLA $\left(M_{\mathrm{n}(\mathrm{PLLA})}\right)=2.1 \times 10^{3},{ }^{1} \mathrm{H}$ NMR による算出 $)$ との銅（I）触媒によるアジド-アルキン環化付加反応 (CuAAC) に供することで, PLLA の末端に $\mathrm{G}_{7}$ を有する プライマーーゲストポリマー複合体 $\left(\mathrm{G}_{7}-\mathrm{PLLA}\right)$ を得た (スキーム 2 $)^{38)}$ 。合成した $\mathrm{G}_{7}-\mathrm{PLLA}$ を酢酸ナトリウム緩 衝液 (0.2 M, pH 6.2) に分散させ, G-1-P および Aquifex aeolicus VF5 由来ホスホリラーゼ存在下, $40-45^{\circ} \mathrm{C}$ で 48 時間激しく撹汼して，つる巻き重合を行った（図 2) ${ }^{39)} 。$ 反応終了後，ろ過により回収した固体を，水，アセトン， クロロホルムで洗浄して未反応原料などを除去した後, 減 圧下，室温で乾燥することで白色固体が得られた。得られ た生成物は，ジメチルスルホキシド（DMSO）のみにわ ずかに溶解したのに対して， $G_{7}$ とPLLA を用いた既往の つる巻き重合により得られた包接錯体は DMSO に可溶で あったことから， $G_{7}-$ PLLA を用いたつる巻き重合による 生成物は, 従来のつる巻き重合生成物である包接錯体とは 明らかに DMSO への溶解性が異なるあのであり，より大 きな分子量の化合物であることが推測された。生成物の $\mathrm{XRD}$ パターンは, $2 \theta=12^{\circ}$ と $19^{\circ}$ にブロードな回折ピー

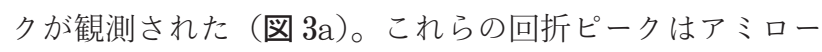

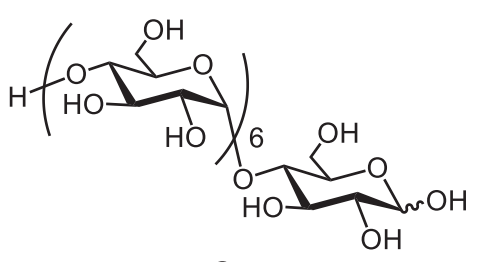

$\mathrm{G}_{7}$

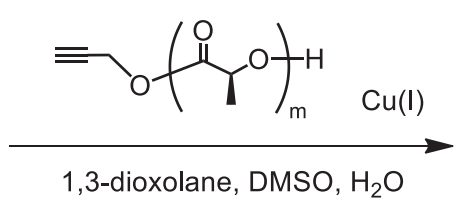

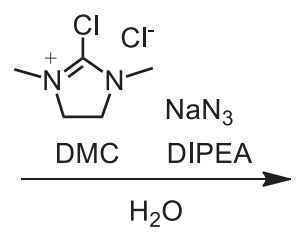

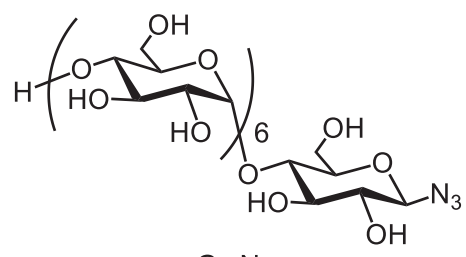

$\mathrm{G}_{7}-\mathrm{N}_{3}$

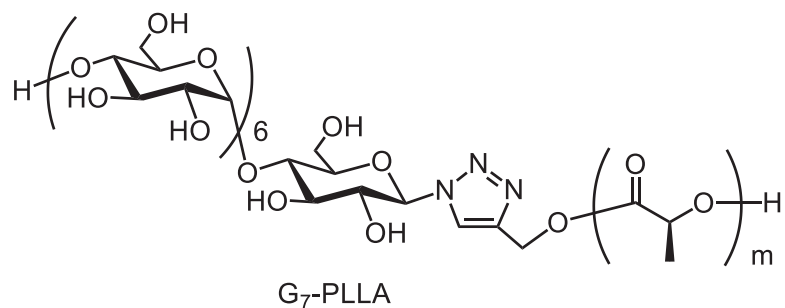

スキーム $2 \quad \mathrm{G}_{7}$-PLLA の合成 


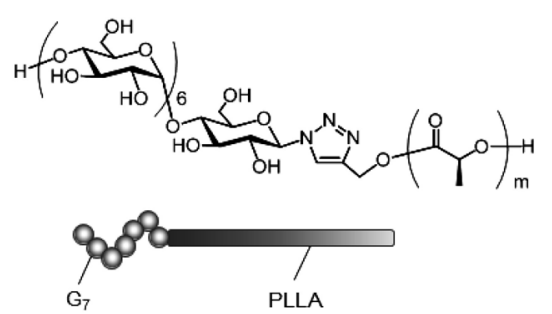

$\mathrm{G}_{7}$-PLLA

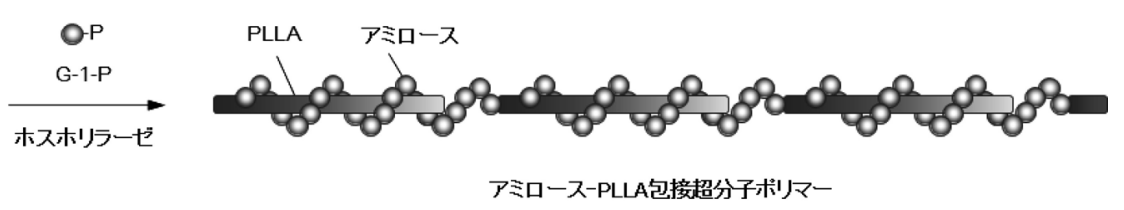

図 2 つる巻き重合によるアミロース-PLLA 包接超分子ポリマーの合成 ${ }^{39)}$

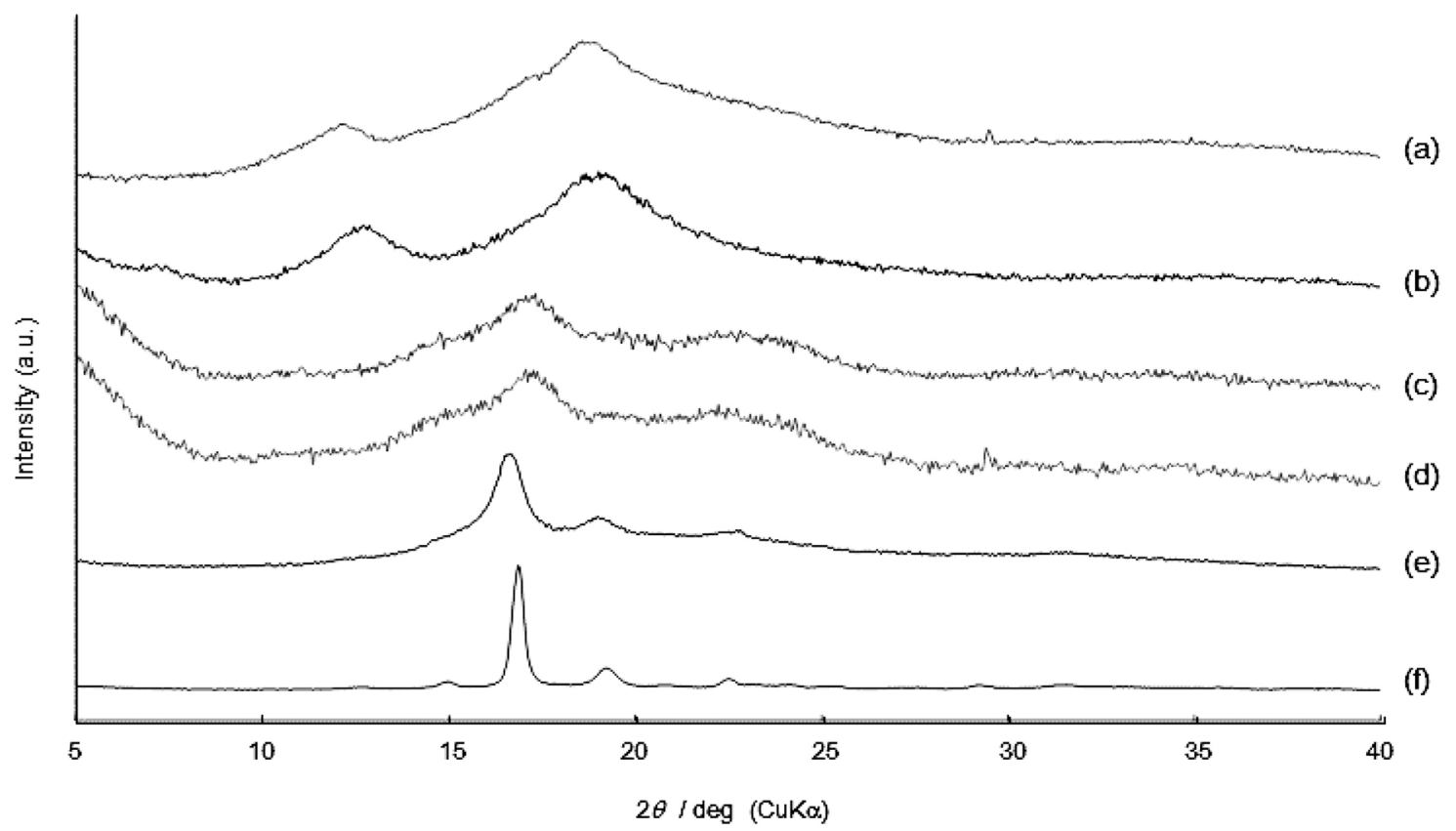

図 3 (a) $G_{7}-P L L A,(b) G_{7}$ とPLLA $\left(G_{7} / P L L A=1 / 15\right)$, (c) $G_{7}$ とPLLA $\left(G_{7} / P L L A=1 / 1\right)$ を用いた つる巻き重合生成物, および (d) アミロース, (e) $\mathrm{G}_{7}$ - PLLA, (f) PLLA の XRD パターン39)

ス， $\mathrm{G}_{7}$-PLLA，PLLA とは異なり， $\mathrm{G}_{7}$ と PLLA を用い た既往のつる巻き重合 $\left(\mathrm{G}_{7} / \mathrm{PLLA}=1 / 15(\mathrm{~mol} / \mathrm{mol})\right)$ に よる包接錯体生成物の回折ピークと一致した（図 $3 \mathrm{~b}, \mathrm{~d}-\mathrm{f}$ )。 さらに, ${ }^{1} \mathrm{H}$ NMR スペクトルでは, $5.1 \mathrm{ppm}$ と 3.6-3.2 ppm にアミロース, $5.2 \mathrm{ppm}$ と $1.5 \mathrm{ppm}$ に PLLA のシグナル が観測された（図 4)。また，生成物のアミロース部分の ヒドロキシ基をアセチル化して GPC 分析を行ったところ, $M_{\mathrm{n}}$ は $5.4 \times 10^{5}$ (スタンダード：ポリスチレン）であり, 原料の $\mathrm{G}_{7}$-PLLA に比べて分子量が大きく増大している ことを確認した ${ }^{40)}$ 。 $\mathrm{G}-1-\mathrm{P} の \mathrm{G}_{7}$-PLLA に対する原料仕 込モル比 $\mathrm{G}-1-\mathrm{P} / \mathrm{G}_{7}-\mathrm{PLLA}$ を $250 / 1$ とした場合, 生成 物中のアミロース部分の重合度は約 100 であり, G-1-P/ $\mathrm{G}_{7}$ - PLLA を 1000/1 まで増加しても変化しなかった。一 方, $\mathrm{G}_{7}$ プライマーと PLLA ゲストポリマーを用いた既往 のつる巻き重合の場合, G-1-P/PLLA の増加とともに生 成物中のアミロース部分の重合度は増加した。 $G_{7}$-PLLA を用いた場合には，アミロース鎖の伸長が PLLA 末端の $\mathrm{G}_{7}$ によって停止するためと考えられる。これらの結果か ら， $\mathrm{G}_{7}$-PLLA を用いたつる巻き重合によって, アミロー
スによるPLLA の包接が連続的に繰り返された構造（図 2）功成る新奇なアミロース-PLLA 包接超分子ポリマー の合成を確認した。

通常, $G_{7}$ プライマーと PLLA ゲストポリマーを用いた 既往のつる巻き重合による包接錯体合成では， $G_{7}$ に対し て過剰量（15 倍モル以上）のPLLA を必要とする。 $\mathrm{G}_{7}$ と PLLA の原料仕込モル比が等量の場合には，包接錯体の 生成を示す回折ピークは観測されず，アミロースの回折ピー クのみが観測される（図 $3 c$ ）。 $\mathrm{G}_{7}-\mathrm{PLLA}$ を用いたつる巻 き重合においては，ゲストポリマーとなるPLLA の末端 に $\mathrm{G}_{7}$ が結合して一分子となっているため, $\mathrm{G}_{7}$ と PLLA のモル比は等量であり，PLLA が過剩に存在しないにも かかわらず，アミロースによる PLLA の包接が確認され た。動的光散乱法により水中で $\mathrm{G}_{7}$-PLLA を分析したと ころ，50-110 nm の凝集体の存在が確認された。水中に おいて $\mathrm{G}_{7}-$ PLLA は， 疎水性の PLLA がコア，親水性の $\mathrm{G}_{7}$ がシェルを形成して凝集していると考えられる。この水 中での $\mathrm{G}_{7}-\mathrm{PLLA}$ の凝集体形成により, $\mathrm{G}_{7}$ 周辺の PLLA 濃度が局所的に高くなり, $\mathrm{G}_{7}$ に対する PLLA の原料モル 

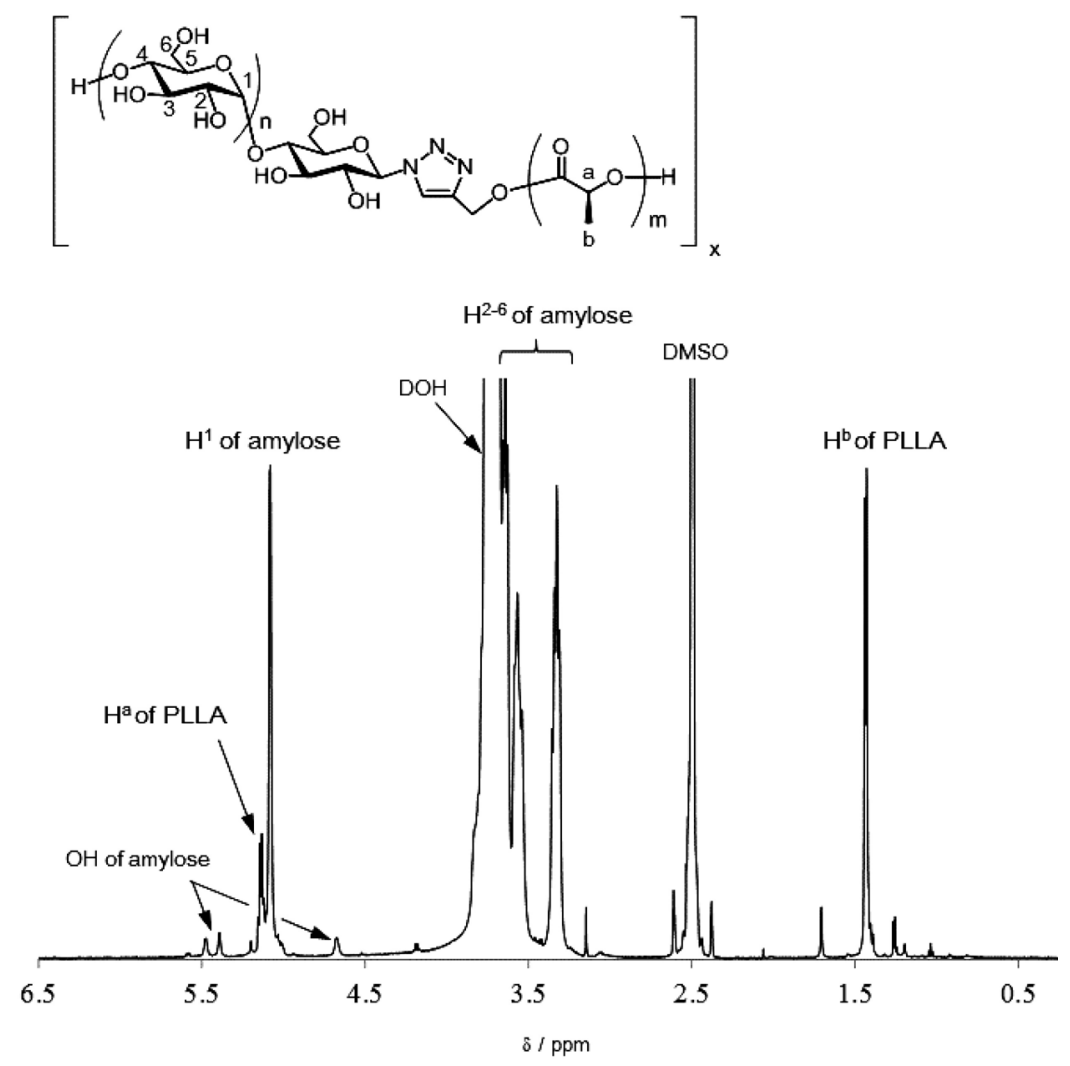

図 $4 \mathrm{G}_{7}$ - PLLA を用いたつる巻き重合生成物の ${ }^{1} \mathrm{H}$ NMR スペクトル $\left(\mathrm{DMSO}-d_{6}\right){ }^{39)}$

比が過剩ではないにもかかわらず， $\mathrm{G}_{7}-\mathrm{PLLA}$ を用いたつ る巻き重合においてアミロースによるPLLAの包接が進 行し，前述のアミロース-PLLA 包接超分子ポリマーが合 成できたと考えられる。

つる巻き重合による超分子ポリマーの合成において，ゲ ストポリマー部分をPTHF に替えたプライマーーゲスト ポリマー複合体 $\mathrm{G}_{7}-\mathrm{PTHF}\left(M_{\mathrm{n}(\mathrm{PTHF})}=1.6 \times 10^{3},{ }^{1} \mathrm{H}\right.$ NMR による算出）を合成して用いた場合には， $\mathrm{G}_{7}$-PLLA の 場合と同様に，アミロースと PTHF から成るアミロースー PTHF 包接超分子ポリマーが得られた ${ }^{41)}$ 。

\section{3. アミロースによるポリ乳酸包接挙動の解明}

ポリ乳酸をゲストポリマーとした既往のつる巻き重合に おいて，PLLA を用いた場合には包接錯体が生成するが， PDLA および PDLLA の場合には包接錯体は生成しない37)。 これはアミロースのらせん内部構造がポリ乳酸のキラリティ を識別可能であることを示唆しており，アミロースと PLLA のらせん構造がともに左巻きらせん構造であるた めと考察される。しかし，アミロースによるポリ乳酸の包 接において，互いの分子鎖方向之包接の関係を示す知見は これまでなかった。ホスホリラーゼを触媒とするアミロー スの酵素合成において，アミロース鎖は還元末端側から非 還元末端側に伸長する。その際，包接される PLLA の分 子鎖はカルボキシ基末端がアミロースの非還元末端側に来 る場合と, 逆に, PLLAのヒドロキシ基末端がアミロー
スの非還元末端側に来る場合の 2 通りが考えられる。アミ ロースによるポリ乳酸の包接において，伸長するアミロー ス鎖とゲストポリマーであるポリ乳酸の分子鎖方向の関係 を明らかにすることを目的として，4 種類のプライマーポリ乳酸複合体を用いてつる巻き重合を行い，その生成物 を解析した ${ }^{42)}$ 。先に合成した PLLA のカルボキシ基末端に $\mathrm{G}_{7}$ を結合した $\mathrm{G}_{7}-\mathrm{PLLA} の$ 他に, PLLAのヒドロキシ基 末端に $\mathrm{G}_{7}$ を結合した PLLA- $\mathrm{G}_{7}$, PDLA のカルボキシ基 末端およびヒドロキシ基末端に $\mathrm{G}_{7}$ を結合した $\mathrm{G}_{7}-\mathrm{PDLA}$, $\mathrm{PDLA}-\mathrm{G}_{7}$ をそれぞれ化学合成し, つる巻き重合のプライ マーーゲストポリマー複合体とした。 $\mathrm{G}_{7}-\mathrm{PDLA}\left(M_{\mathrm{n}(\mathrm{PDLA})}=\right.$ $2.1 \times 10^{3},{ }^{1} \mathrm{H}$ NMR による算出）はカルボキシ基末端に アルキンを有する PDLA と $\mathrm{G}_{7}-\mathrm{N}_{3}$ を $\mathrm{CuAAC}$ に供するこ とで， $\mathrm{G}_{7}$-PLLA と同様の方法で合成した。一方，ポリ乳 酸のヒドロキシ基末端に $\mathrm{G}_{7}$ を有する $\mathrm{PLLA}-\mathrm{G}_{7}\left(M_{\mathrm{n}(\mathrm{PLLA})}=\right.$ $1.9 \times 10^{3},{ }^{1} \mathrm{H}$ NMR による算出 $)$ と $\mathrm{PDLA}-\mathrm{G}_{7}\left(M_{\mathrm{n}(\mathrm{PDLA})}=\right.$ $1.9 \times 10^{3},{ }^{1} \mathrm{H}$ NMR による算出）は，メ夕ノールを開始 剤としたラクチドの開環重合により得た $\mathrm{MeO}-\mathrm{PLLA}$ お

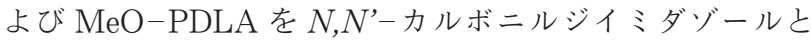
反応することでポリ乳酸のヒドロキシ末端を活性エステル 化，続いて，N-プロパルギルアミンを作用させてプロパル ギルアミド化した後， $\mathrm{G}_{7}-\mathrm{N}_{3}$ との $\mathrm{CuAAC}$ に供すること で合成した（スキーム 3$)$ 。

合成した 4 種類のプライマーーゲストポリマー複合体 $\left(\mathrm{G}_{7}-\mathrm{PLLA}\right.$, PLLA $-\mathrm{G}_{7}, \mathrm{G}_{7}-\mathrm{PDLA}$, PDLA $\left.-\mathrm{G}_{7}\right)$ を用 


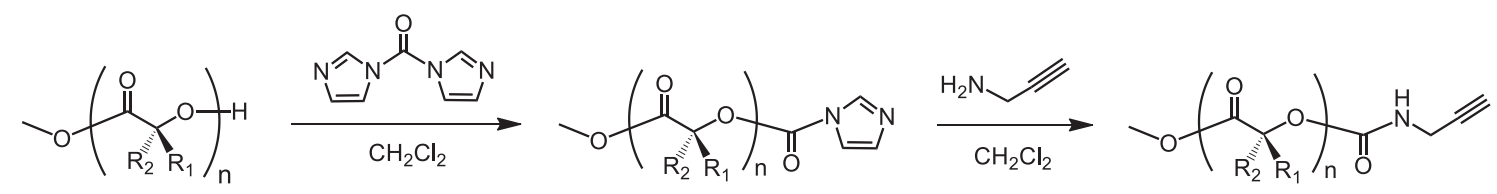

MeO-PLLA : $\mathrm{R}_{1}=\mathrm{CH}_{3}, \mathrm{R}_{2}=\mathrm{H}$

MeO-PDLA : $\mathrm{R}_{1}=\mathrm{H}, \mathrm{R}_{2}=\mathrm{CH}_{3}$

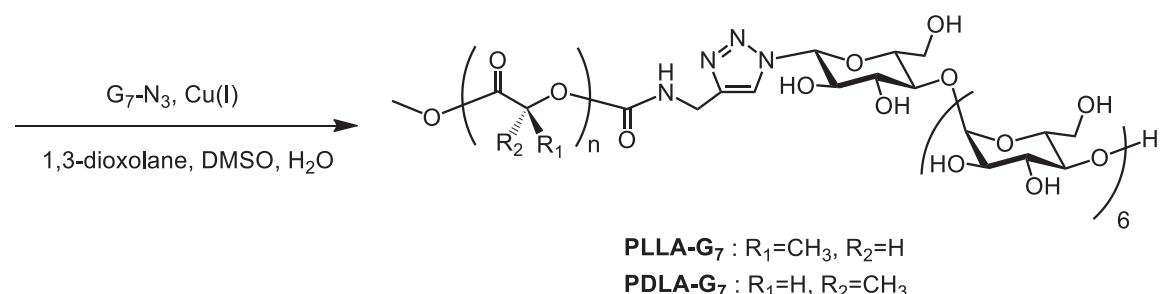

スキーム 3 PLLA $-\mathrm{G}_{7}$ と $\mathrm{PDLA}-\mathrm{G}_{7}$ の合成
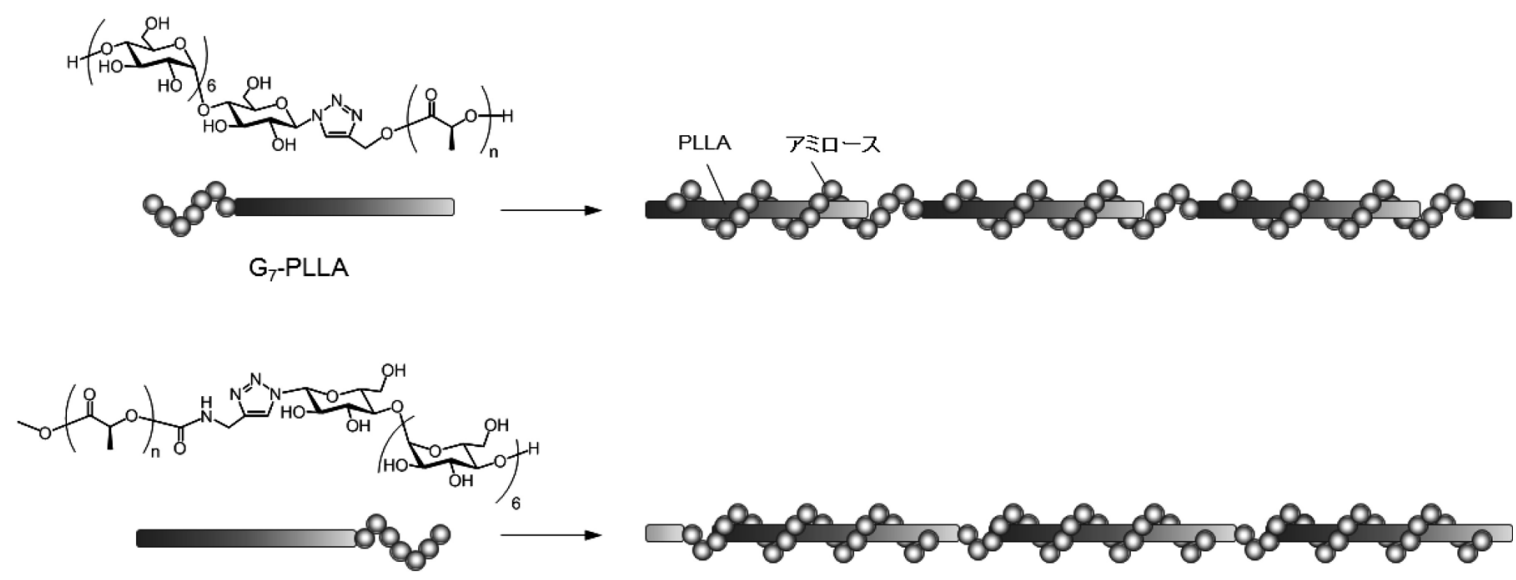

PLLA-G 7
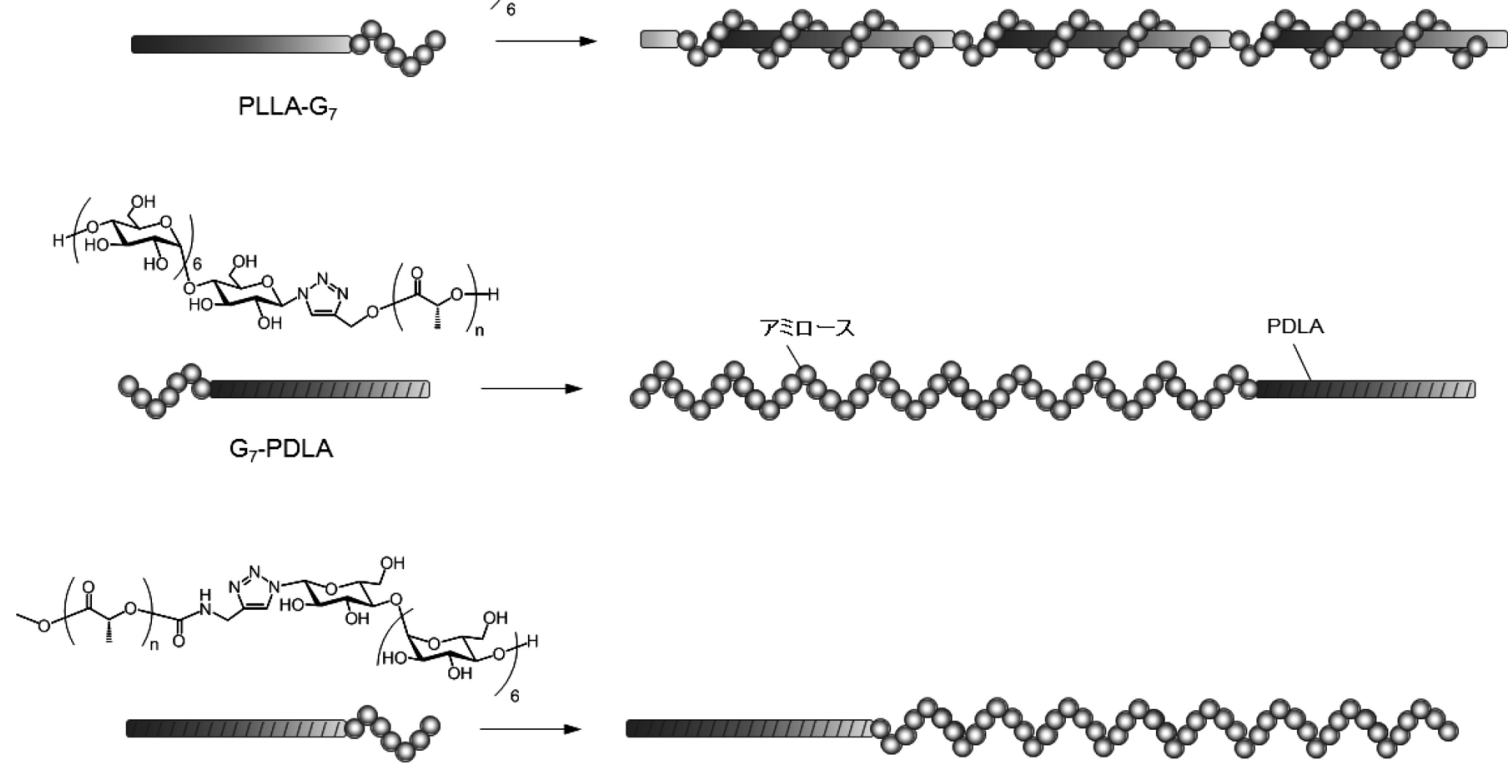

PLLA-G 7

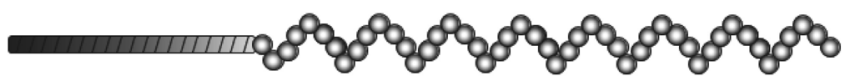

図 $5 \mathrm{G}_{7}$-ポリ乳酸複合体を用いたホスホリラーゼによる酵素重合反応 ${ }^{42}$

いて，つる巻き重合条件下にてホスホリラーゼを触媒とす る反応を行った（図 5)。PLLA $-G_{7}$ を用いた場合には, $\mathrm{G}_{7}$ - PLLA のときと同様に $2 \theta=12^{\circ}$ と $19^{\circ}$ にブロードな XRD 回折ピークが観測され, ${ }^{1} \mathrm{H}$ NMR スペクトルであ アミロースと PLLA のシグナルが確認されたため, 包接 超分子ポリマーの生成が示唆された。一方, G $\mathrm{G}_{7}$-PDLA ま
たは PDLA $-\mathrm{G}_{7}$ を用いた場合には，アミロースによる包 接の形成に由来する回折ピークは観測されず，アミロース のみに由来する回折ピークが観測された。 ${ }^{1} \mathrm{H}$ NMR スペ クトルでは, $\mathrm{G}_{7}-\mathrm{PDLA}$ および PDLA $-\mathrm{G}_{7}$ いずれの場合 にもアミロースと PDLA のシグナルが確認されたため, PDLA 末端の $\mathrm{G}_{7}$ からアミロース鎖の伸長は進行したもの 
の, PDLA 鎖を包接していないことが示唆された。また, 各生成物の DMSO 可溶部, およびそれらを $1 \mathrm{M} \mathrm{NaOH}$ 水溶液で処理することでポリ乳酸部分を加水分解して得ら れたアミロース部分を GPC 分析した。 $G_{7}-$ PLLA および PLLA $-\mathrm{G}_{7}$ から得られた生成物の場合には, $\mathrm{NaOH}$ 水溶 液処理後の分子量が大きく低下したのに対して $\left(\mathrm{G}_{7}-\mathrm{PLLA}\right.$ : $M_{\mathrm{n}}=1.6 \times 10^{5} \rightarrow 2.5 \times 10^{4}, \mathrm{PLLA}-\mathrm{G}_{7}: M_{\mathrm{n}}=1.2 \times 10^{5} \rightarrow 2.8$ $\left.\times 10^{4}\right), \mathrm{G}_{7}-\mathrm{PDLA}$ および PDLA $-\mathrm{G}_{7}$ の場合には, 分子 量の低下はわずかであった $\left(\mathrm{G}_{7}-\mathrm{PDLA}: M_{\mathrm{n}}=4.7 \times 10^{4} \rightarrow\right.$ $\left.4.1 \times 10^{4}, \mathrm{PDLA}-\mathrm{G}_{7}: M_{\mathrm{n}}=6.6 \times 10^{4} \rightarrow 5.8 \times 10^{4}\right)$ 。これ らの結果からも, $\mathrm{G}_{7}-\mathrm{PLLA}$ および PLLA $-\mathrm{G}_{7}$ の場合には 伸長するアミロース鎖による PLLA の包接が進行して包接 超分子ポリマーが生成する一方, $\mathrm{G}_{7}$-PDLA および PDLA $-\mathrm{G}_{7}$ の場合にはアミロース鎖が伸長するのみで, PDLA 鎖を包接しないことが示唆された。以上の結果より, ホス ホリラーゼを触媒とするアミロースの酵素合成反応場にお いて，アミロースはPLLA を包接するが PDLA は包接し ない, 即ち, ポリ乳酸のキラリティを識別可能であること, さらにPLLA を包接するときには, PLLA の分子鎖方向 は影響せず, PLLA のどちらの分子鎖方向からもアミロー スが PLLA を包接可能なことが明らかとなった。

\section{4. ハイパーブランチ型アミロースーポリ乳酸包接} 超分子ポリマーの合成

$\mathrm{G}_{7}-\mathrm{PLLA}$ を用いたつる巻き重合によって直鎖状のアミ ロース-PLLA 包接超分子ポリマーが得られたことを基に,
分子内に 2 つの PLLA 鎖を有するプライマー PLLA 複 合体を用いてつる巻き重合を行えば，伸長したアミロース による PLLA の包接がネットワーク状に進行し，ハイパー ブランチ型の包接超分子ポリマーが合成できると考えた。 5 -ヒドロキシメチル-2,2,5-トリメチル-1,3-ジオキサン から 2 工程で合成した 2 つのビロキシ基を有する $2,2-$

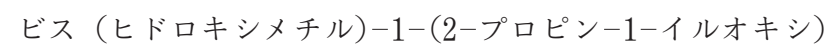

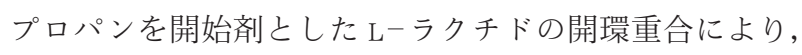
1 つの末端アルキンを有する二分岐 PLLA を合成した後, $\mathrm{G}_{7}-\mathrm{N}_{3}$ との $\mathrm{CuAAC}$ に供することで, 分子内に 2 つの PLLA 鎖を有するプライマーーゲストポリマー複合体 $\left(\mathrm{G}_{7}-\right.$ $\left.\mathrm{PLLA}_{2}\right)$ を合成した $\left(M_{\mathrm{n}(\mathrm{PLLA})}=2.0 \times 10^{3},{ }^{1} \mathrm{H}\right.$ NMR に よる算出）（スキーム 4 ）。合成した $G_{7}-P_{L L A}$ を用いて つる巻き重合を行った（図 6 ${ }^{43)}$ 。G-1-P/ $\mathrm{G}_{7}-\mathrm{PLLA}_{2}$ の 原料仕込モル比を50/1 とした場合, 得られた生成物の $\mathrm{XRD}$ パターンは, $2 \theta=12^{\circ}$ と $19^{\circ}$ にブロードな回折ピー クが観測され， $G_{7}$ とPLLA を用いた既往のつる巻き重合 による包接錯体生成物, および $\mathrm{G}_{7}-\mathrm{PLLA}$ を用いたつる 巻き重合による直鎖状の包接超分子ポリマーの回折パター ンと一致した。また， ${ }^{1} \mathrm{H}$ NMR スペクトルでもアミロー スと PLLA のシグナルが確認された。これらの結果より, $\mathrm{G}_{7}-\mathrm{PLLA}_{2}$ を用いたつる巻き重合によって, $\mathrm{G}_{7}$ から伸長 したアミロース鎖によるPLLA 鎖の包接がネットワーク 状に広がったハイパーブランチ型のアミロース-PLLA 包 接超分子ポリマーが合成できたことを確認した。一方，G $-1-\mathrm{P} / \mathrm{G}_{7}-\mathrm{PLLA}_{2}$ の原料仕込モル比を $250 / 1$ とした場合,
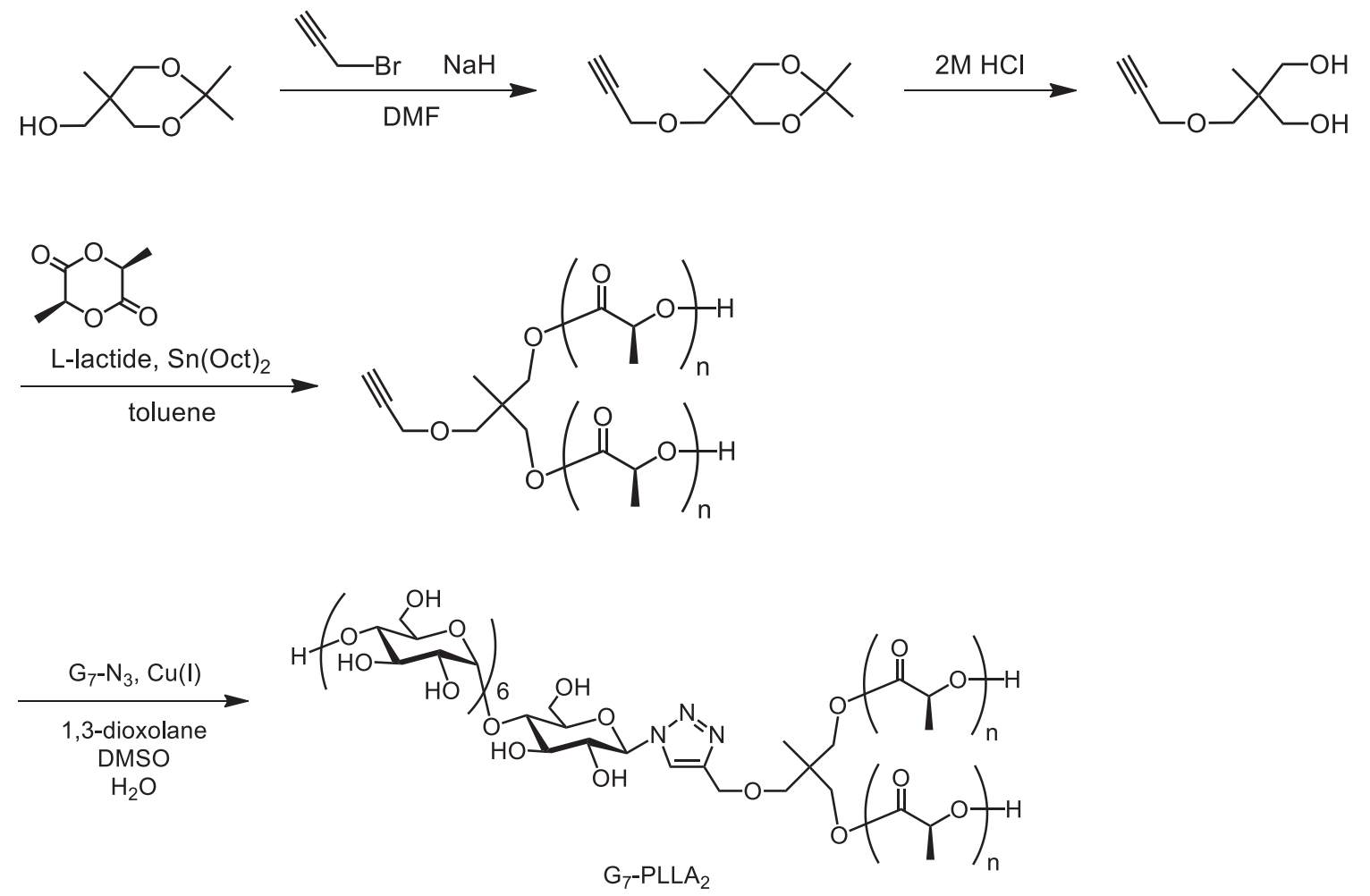

スキーム $4 \quad \mathrm{G}_{7}-\mathrm{PLLA}_{2}$ の合成 


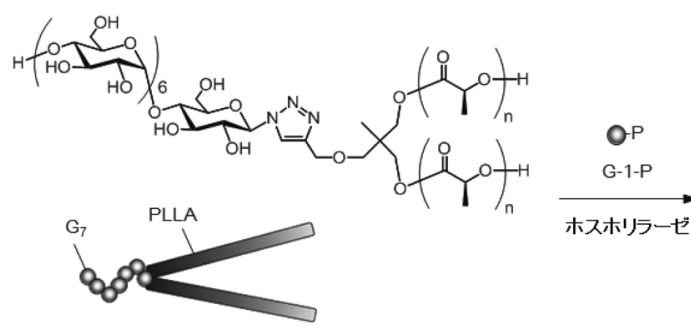

$\mathrm{G}_{7}-\mathrm{PLLA}_{2}$

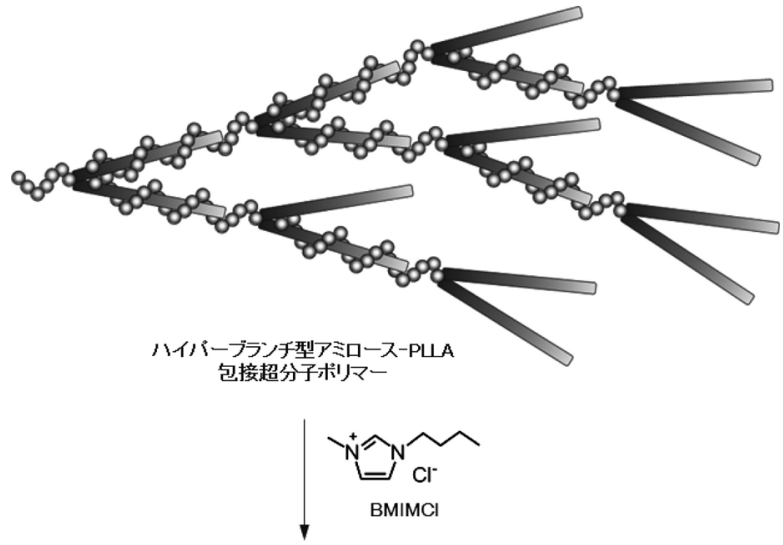

溶媒置換(水中)

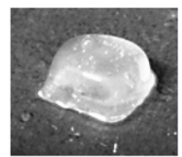

イオンゲル

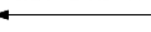

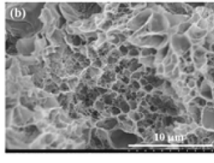

クライオゲル

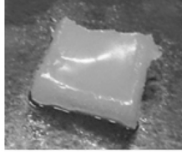

ハイドロゲル

図 6 つる巻き重合によるハイパーブランチ型アミロース-PLLA 包接超分子ポリマーの合成とゲル作製 43)

アミロースによるPLLA の包接を示す回折ピークに加え て，アミロースのみに由来する回折ピークあわずかに観測 されたため，G-1-P 過剩の条件下では，PLLA 鎖を包接 していないアミロース鎖が一部存在するハイパーブランチ 型超分子ポリマーが生成することが明らかとなった。

$\mathrm{G}_{7}-\mathrm{PLLA}_{2}$ をプライマーーゲストポリマー複合体とし て用いたつる巻き重合により得られたハイパーブランチ型 アミロース-PLLA 包接超分子ポリマーは，アミロースを 溶解するイオン液体 1-ブチル-3-メチルイミダゾリウム クロリド $(\mathrm{BMIMCl})$ と $60^{\circ} \mathrm{C} て ゙$ 混合して溶解した後，室 温にするとイオンゲルを形成した（図 6)。 $G_{7}-$ PLLA か ら得られた直鎖状のアミロース-PLLA 包接超分子ポリマー は，BMIMCl と混合してあイオンゲルは得られなかった ことから，八イパーブランチ型超分子ポリマーのネットワー ク構造がイオンゲルの形成に寄与していることが示唆され た。さらに，得られたイオンゲルを水に浸して溶媒を水へ 之置換することで，八イドロゲルが得られた。これらのイ オンゲルおよびハイドロゲルの動的粘弾性を測定すると, いずれの場合においても貯蔵弾性率 $\left(G^{\prime}\right)$ は損失弾性率 （G”）よりも高い值を示したことから，ゲルの形成が確認 できた。さらに，得られた八イドロゲルを凍結乾燥するこ とで，クライオゲルが作製できた。以上の結果より， $\mathrm{G}_{7}-$ $\mathrm{PLLA}_{2}$ を用いたつる巻き重合によって，アミロースによ る PLLA の包接を利用したネットワーク構造を構築する ことができ，イオンゲル，八イドロゲル，クライオゲルを 形成するハイパーブランチ型アミロース-PLLA 包接超分 子ポリマーが創製できた。

\section{5.おわりに}

本総説では，ホスホリラーゼを触媒としたつる巻き重合
によるアミロース包接化合物の合成において，プライマーの $\mathrm{G}_{7}$ をゲストポリマー末端に結合したプライマーーゲストポ リマー複合体を用いた新奇なアミロース包接超分子ポリマー の合成と，そのゲル形成について概説した。このようなアミ ロースによる高分子の包接を基盤とした超分子ポリマーの 合成はこれまでに例が無く，化学合成と酵素合成を組み合 わせることによって創製された新しい化合物である。これら 一連の研究は, プライマーーゲストポリマー複合体を自在 に設計できる有機合成化学と，ホスホリラーゼを触媒とする アミロースの酵素合成を巧みに組み合わせることで達成さ れた。エネルギー多糖であるアミロースは力学的に脆弱な ため，セルロースなどの構造多糖と比べてマテリアルとして の利用は限られているのか現状である。本手法は，アミロー スとポリ乳酸の融合に留まらず，他の疎水性ポリマーへの 適用も可能であるため，アミロースのらせん内部にさまざ まな高分子鎖を包接させることでアミロースの物性に与え る影響を理解するとと屯に，より有用なアミロース包接超 分子マテリアルの創製へと発展させることによって，アミ ロースのマテリアルとしての利用価值が高まることが期待 される。また，有機合成化学上酵素工学を効果的任組み合 わせた化学-酵素合成法が，高分子化学をはじめとするさ まざまな研究分野において幅広く利用され，新規マテリア ルの創製や新規合成法の開発へとつながることを強く望む。

\section{謝辞}

本研究は, 科学研究費助成事業, 泉科学技術振興財団研 究助成, マッダ財団マッ夕゙研究助成の支援を受けて実施し たものであり，ここに感謝の意を表する。また，ホスホリ ラーゼは江崎グリコ株式会社からご提供いただいた。謝意 を表する。 


\section{文献}

1) S. Shoda, H. Uyama, J. Kadokawa, S. Kimura, S. Kobayashi, Chem. Rev., 116, 2307 (2016).

2) J. Seibel, H.-J. Jördening, K. Buchholz, Biocat. Biotrans., 24, 311 (2006).

3) T. Murata, T. Usui, Trends Glycosci. Glycotechnol., 12, 161 (2000).

4) S. Shoda, "Enzymatic glycosylation" in Glycoscience, Vol. II, p.1465, Springer, New York (2001).

5) J. Thiem, "Enzymatic glycosylation by hydrolases" in Glycoscience, Vol. II, p. 1387, Springer, New York (2008).

6) P. Bojarová, V. Křen, Trends Biotechnol., 27, 199 (2009).

7) M. Kitaoka, K. Hayashi, Trends Glycosci. Glycotechnol., 14, 35 (2002).

8) M. Yanase, T. Takaha, T. Kuriki, J. Sci. Food Agric., 86, 1631 (2006)

9) G. Ziegast, B. Pfannemüller, Carbohydr. Res., 160, 185 (1987).

10) K. Fujii, H. Takata, M. Yanase, Y. Terada, K. Ohdan, T. Takaha, S. Okada, T. Kuriki, Biocat. Biotrans., 21, 167 (2003).

11) H. Takata, T. Takaha, S. Okada, M. Takagi, T. Imanaka, J. Ferment. Bioeng., 85, 156 (1998).

12) R. L. Shogren, R. V. Greene, Y. V. Wu, J. Appl. Polym. Sci., 42, 1701 (1991).

13) R. L. Shogren, Carbohydr. Polym., 22, 93 (1993).

14) A. Star, D. W. Steuerman, J. R. Heath, J. F. Stoddart, Angew. Chem. Int. Ed., 41, 2508 (2002).

15) M. Ikeda, Y. Furusho, K. Okoshi, S. Tanahara, K. Maeda, S. Nishino, T. Mori, E. Yashima, Angew. Chem. Int. Ed., 45, 6491 (2006).

16) T.Kida, T.Minabe, S. Okabe, M. Akashi, Chem. Commun., 1559 (2007).

17) Y. Kaneko, T. Kyutoku, N. Shimomura, J. Kadokawa, Chem. Lett., 40, 31 (2011).

18) R. Rachmawati, A. J. J. Woortman, K. Loos, Biomacromolecules, 14, 575 (2013).

19) K. Kumar, A. J. J. Woortman, K. Loos, Biomacromolecules, 14, 1955 (2013).

20) R. Rachmawati, A. J. J. Woortman, K. Loos, Macromol. Biosci., 13, 767 (2013).

21) R. Rachmawati, A. J. J. Woortman, K. Loos, Macromol. Biosci., 14, 56 (2014).
22) S. A. - Abhari, A. J. J. Woortman, A. A. C. M. (L.) Oudhuis, R. J. Hamer, K. Loos, Starch-Stärke, 66, 251 (2014).

23) J. Kadokawa, Polymers, 4, 116 (2012).

24) J. Kadokawa, Biomolecules, 3, 369 (2013).

25) J. Kadokawa, Y. Kaneko, H. Tagaya, K. Chiba, Chem. Commun., 449 (2001).

26) J. Kadokawa, Y. Kaneko, A. Nakaya, H. Tagaya, Macromolecules, 34, 6536 (2001).

27) J. Kadokawa, Y. Kaneko, S. Nagase, T. Takahashi, H. Tagaya, Chem. Eur. J., 8, 3321 (2002).

28) J. Kadokawa, A. Nakaya, Y. Kaneko, H. Tagaya, Macromol. Chem. Phys., 204, 1451 (2003).

29) Y. Kaneko, K. Beppu, J. Kadokawa, Biomacromolecules, 8, 2983 (2007).

30) Y. Kaneko, K. Beppu, J. Kadokawa, Macromol. Chem. Phys., 209, 1037 (2008).

31) Y.Kaneko, Y.Saito, A. Nakaya, J.Kadokawa, H.Tagaya, Macromolecules, 41, 5665 (2008).

32) Y. Kaneko, K. Beppu, T. Kyutoku, J. Kadokawa, Polym. J., 41, 279 (2009).

33) Y. Kaneko, K. Beppu, J. Kadokawa, Polym. J., 41, 792 (2009).

34) Y. Kaneko, K. Fujisaki, T. Kyutoku, H. Furukawa, J. Kadokawa, Chem. Asian J., 5, 1627 (2010).

35) S. Nomura, T. Kyutoku, N. Shimomura, Y. Kaneko, J. Kadokawa, Polym. J., 43, 971 (2011).

36) J. Kadokawa, S. Nomura, D. Hatanaka, K. Yamamoto, Carbohydr. Polym., 98, 611 (2013).

37) Y. Kaneko, K. Ueno, T. Yui, K. Nakahara, J. Kadokawa, Macromol. Biosci., 11, 1407 (2011).

38) T. Tanaka, H. Fukuhara, S. Shoda, Y. Kimura, Chem. Lett., 42, 197 (2013).

39) T. Tanaka, S. Sasayama, S. Nomura, K. Yamamoto, Y. Kimura, J. Kadokawa, Macromol. Chem. Phys., 214, 2829 (2013).

40) T. Tanaka, A. Tsutsui, K. Tanaka, K. Yamamoto, J. Kadokawa, Biomolecules, In press.

41) T. Tanaka, A. Tsutsui, R. Gotanda, S. Sasayama, K. Yamamoto, J. Kadokawa, J. Appl. Glycosci., 62, 135 (2015).

42) T. Tanaka, S. Sasayama, K. Yamamoto, Y. Kimura, J. Kadokawa, Macromol. Chem. Phys., 216, 794 (2015).

43) T. Tanaka, R. Gotanda, A. Tsutsui, S. Sasayama, K. Yamamoto, Y. Kimura, J. Kadokawa, Polymer, 73, 9 (2015). 